\title{
Advanced Catalyst Supports for PEM Fuel Cell Cathodes
}

\author{
Lei Du, ${ }^{a, b, c}$ Yuyan Shao, ${ }^{a, *}$ Junming Sun, ${ }^{b}$ Geping Yin, ${ }^{c}$ Jun Liu, ${ }^{a, *}$ Yong Wang ${ }^{a, b, *}$ \\ ${ }^{a}$ Pacific Northwest National Laboratory, Richland, WA 99352 (US) \\ ${ }^{\mathrm{b}}$ The Gene and Linda Voiland School of Chemical Engineering and Bioengineering, Washington State \\ University, Pullman, WA 99164 (US) \\ ${ }^{c}$ School of Chemical Engineering and Technology, Harbin Institute of Technology, Harbin 150001 (China) \\ *Email: yuyan.shao@pnnl.gov, jun.liu@pnnl.gov, yong.wang@pnnl.gov
}

Keywords: support materials, PEM fuel cells, carbon, metal oxide, hybride composite, durability

\begin{abstract}
Electrocatalyst support materials are key components for polymer exchange membrane (PEM) fuel cells, which play a critical role in determining electrocatalyst durability and activity, mass transfer and water management. The commonly-used supports, e.g. porous carbon black, cannot meet all the requirements under the harsh operation condition of PEM fuel cells. Great efforts have been made in the last few years in developing alternative support materials. In this paper, we selectively review recent progress on three types of important support materials: carbon, non-carbon and hybrid carbon-oxides nanocomposites. A perspective on future $\mathrm{R} \& \mathrm{D}$ of electrocatalyst support materials is also provided.
\end{abstract}

\section{Introduction}

Electrocatalyst support is one of the most critical components in polymer electrolyte membrane (PEM) fuel cells and is generally employed to load and disperse catalytic metal nanoparticles, forming the catalyst layer (CL) sandwiched between PEM and gas diffusion layer (GDL) [1-3]. Figure 1 shows the schematic illustration of membrane electrode assembly (MEA) - the core component of a PEM fuel cell. The electrocatalyst support materials need 
to provide not only stable loading sites for catalytic nanoparticles, but also pathways for both electron and mass transfer by forming continuous porous channels. Therefore, the catalyst support plays a critical role for PEM fuel cell performance and durability. Usually, the electrocatalysts of PEM fuel cell suffer degradation, the mechanism of which includes dissolution, agglomeration and/or detachment of catalytic nanoparticles (refer to Cherevko and Mayrhofer's paper in the same Electrocatalysis Special Issue [4]). Especially, the severe corrosion of supports will accelerate electrocatalyst degradation (Figure 1) [5-9]. This is because the support corrosion will damage the loading sites and weaken the interaction between support and nanoparticles, resulting in agglomeration and/or detachment of catalytic metal nanoparticles [10-14]. To avoid these issues, the support materials should be chemically and electrochemically stable, having strong interaction with catalytic nanoparticles that favors electrode reactions, possessing high electrical conductivity and stable porous structure.

The commonly-used support materials cannot meet the requirements, particularly on the cathode side where the oxygen reduction reactions (ORR) take place. Oxygen electrocatalysis is the cornerstone for sustainable energy conversion, ranging from the conversion of chemicals into electrical energy referring to the utilization of stored fuels in galvanic cells (representative: ORR cathodes in PEM fuel cells, readers are suggested to refer to Strasser's [15] and Stamenkovic's [16] papers in the same Electrocatalysis Special Issue) to the reverse conversion in electrolysis (representative: oxygen evolution reactions in Electrolyzers, refer to Herranz and Schmidt's paper in the same Electrocatalysis Special Issue [17]) [18-23]. The theoretical potential is $\sim 1.23 \mathrm{~V}$ vs. standard hydrogen electrode (SHE) in aqueous solution. This presents great challenges for electrocatalysts due to severe working conditions of high working electrode potential and the oxygen-rich environment, especially under the frequent start-up and shut-down operations [24-29]. The most widely used support materials, i.e. porous carbon black, can be corroded seriously under this working condition [10-14,24-27]. The development of support materials is of great practical significance for PEM fuel cells. 


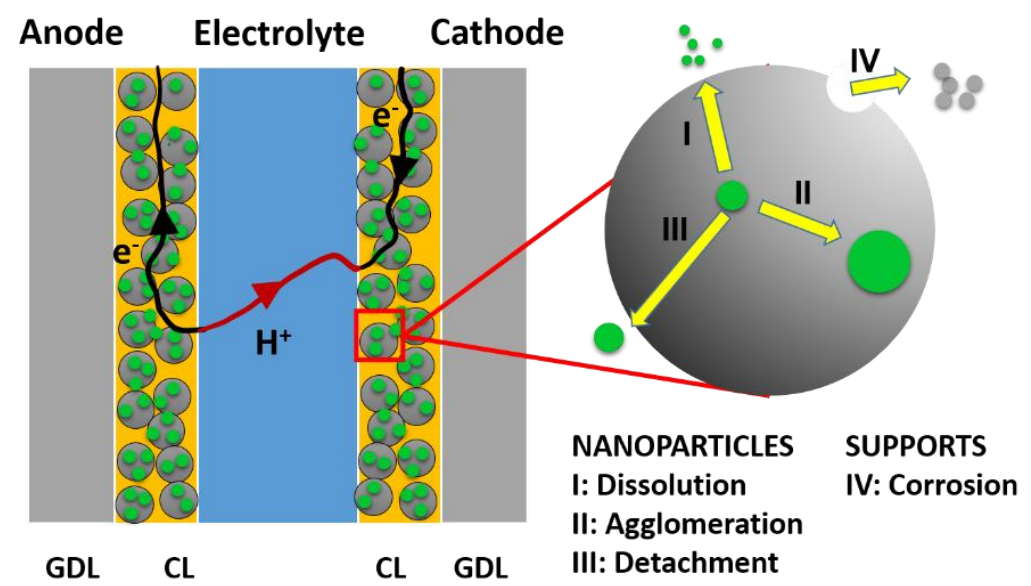

Figure 1. Schematic illustration of MEA and the degradation of electrocatalysts.

This paper aims to provide a critical review on recent development of electrocatalyst support for PEM fuel cells. For the past few years, there have been excellent review papers related with the topics of fuel cells catalysts support [3,30-42]. The focus of this paper is to critically evaluate the status and challenges of PEM fuel cell catalyst support using a few examples and to provide a perspective on its future direction.

\section{Carbon materials}

Carbon is the most widely used support material for PEM fuel cell catalysts because of its high electrical conductivity, accessibility and affordability, relatively high chemical and electrochemical stability. Carbon materials with multi-dimensional structures provide great opportunities in electrocatalyst design [39]. In this regard, the investigation of carbon can also provide guidance for the design and synthesis of alternative support materials.

As discussed above, the severe working conditions in PEM fuel cells can lead to severe corrosion of carbon formulated as:

$$
\mathrm{C}+2 \mathrm{H}_{2} \mathrm{O} \rightarrow \mathrm{CO}_{2}+4 \mathrm{H}^{+}+4 \mathrm{e}^{-}, \varphi^{0}=0.207 \text { V vs. SHE }
$$

A dramatic decrease in the thickness of cathode catalyst layer consisting of Pt/Vulcan carbon has been observed after accelerating degradation test (ADT) holding the electrode at $1.2 \mathrm{~V}$ for $400 \mathrm{~h}$ (Figure 2a and 2b) [43] using the U.S. Drive Partnership Test protocols [44]. However, the reduction in catalyst layer thickness seems not directly correlated with the carbon 
corrosion because the carbon corrosion rate does not match well with the catalyst layer thinckness reduction [45]. Therefore, the thinning could be caused by the compaction of materilas along with the severe carbon corrosion in the catalyst layer. Besides, the porosity of catalyst layer decreased by more than $50 \%$ after ADT for only $40 \mathrm{~h}$ (Figure 2c and 2d), especially near the area with high Pt loading $[43,46]$. The loss of porosity could be due to the thickness reduction of catalyst layer; the unstable carbon materials are compressed into the porous structure. The severe corrosion, which decreases the active sites, and structure change of carbon supports within catalyst layer will jeopardize not only activity but also mass transfer. In addition, severe agglomeration of catalytic metal nanoparticles lowers the efficient density of active sites on the surface (Figure 2e and 2f) [46,47]. These ongoing variations result in significant performance degradation during the fuel cell operation $[43,46,47]$. TEM is a powerful tool to investigate the morphology changes. Figure $2 \mathrm{~g}$ and $2 \mathrm{~h}$ show identical TEM images of the same area before and after ADT, which reveals severe carbon corrosion, dissolution, agglomeration and detachment of nanoparticles [11-13]. Readers are directed to refer to Arenz's paper in the same Electrocatalysis Special Issue [48]. Another problem with carbon support corrosion is that the catalyst layer becomes hydrophilic, which hinders the removal of excess water.

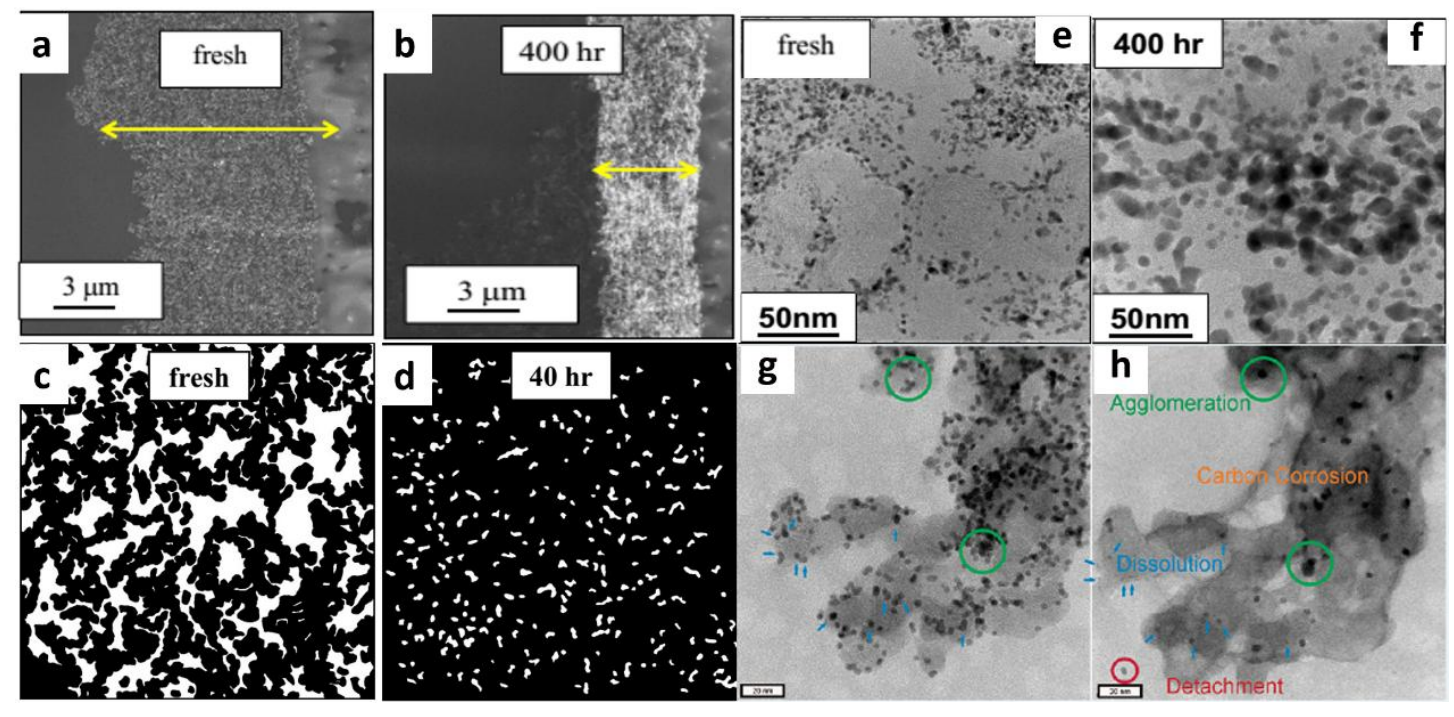

Figure 2. (a,b) The cross-section SEM images, [43] (c,d) the pore distributions of catalyst layer [43,46] and $(e, f)$ the TEM images of the catalysts at cathode $[46,47](a, c, e)$ before and $(b, d, f)$ after the ADT by 
holding the electrode at $1.2 \mathrm{~V}$ using the U.S. Drive Partnership test protocols $\left(80{ }^{\circ} \mathrm{C}, \mathrm{H}_{2} / \mathrm{N}_{2}, 100 \% \mathrm{RH}\right)$; the identical location TEM images of Pt/C (g) before and (h) after ADT (3600 cycles between 0.4 and 1.4 $\mathrm{V}$ with a sweep rate of $1 \mathrm{~V} \mathrm{~s}^{-1}$ ), reproduced with permission from ref. [12]. Copyright (2012) American Chemical Society.

Because of the poor corrosion resistance for common carbon black, some novel carbon materials have been investigated, which include carbon nanotube (CNT, 1D) [49-57], graphene (2D) [58-60] and 3D structural carbon materials such as porous carbon [61-64], carbon nanocomposites [65-68], 3D graphene [69,70] and highly ordered porous carbon [71,72]. Several excellent reviews have been published on CNT [31,42,52], graphene [37,41] and $3 \mathrm{D}$ carbon [34]. In this paper, we mainly focus on general challenges for carbon supports and the strategies to address them. In addition to the enhanced corrosion resistance, the charge transfer and mass transfer at the triple-phase boundaries of gas, catalyst and ionomer are crucial for device performance. Usually, the surface chemistry of support decides the loading sites of catalytic nanoparticles, which determine the number of active sites. On the other hand, high porosity, wide transport channels and lower tortuosity are beneficial for mass transfer. Therefore, the support materials should present these properties.

The highly graphitized carbon materials particularly show improved stability [43]. However, the highly graphitized carbon has much fewer nucleation sites for metal nanoparticle deposition therefore it is challenging to uniformly load metal catalysts. In order to address this issue, approaches such as non-covalent polyelectrolyte functionalization $[40,54,55]$ and strong oxidation (to intentionally produce functional groups and defect sites) $[31,49,73,74]$ are needed. In addition, N-doping, which is another method to introduce nucleation sites on carbon materials, is beneficial for stabilizing nanoparticles [75]. Another interesting strategy is to use $3 \mathrm{D}$ carbon materials or composites to capture dissolved $\mathrm{Pt}$ species and force them to redeposit onto carbon support. A good example is the composite of pre-made Pt/graphene sheets and carbon black, among which the graphene acts as a mesh to prevent the Pt nanoparticles from dissolving into the electrolyte and the extra carbon black is used to capture Pt species, which provides the active sites to renucleate the Pt nanoparticles 
[65]. In addition, highly ordered and porous carbon materials with well-defined 3D structure and high stability are also superior supports for PEM fuel cells [61-64,71,72]. Some smaller catalyst nanoparticles were observed in pores after the ADT, which can be assigned to the capturing effect and the exposure of small nanoparticles in the pores when the edges of porous materials are corroded [61]. Recently, the so-called "solid core type support" is used to prevent the catalytic nanoparticles from being trapped in small pores, so that the utilization of catalysts will be improved [76].

Other new functionalized carbon materials (e.g., nitrogen-doped graphene tube, carbon nanotube, etc.) have also been investigated as catalyst support. Figure $3 \mathrm{a}$ present $\mathrm{N}$ doped CNTs (N-CNTs) with large diameter and a few graphene layers synthesized by pyrolysis-acid leaching-pyrolysis in the presence of $\mathrm{Fe}, \mathrm{N}$ and carbon precursors. The N-CNTs present bamboo-like structure with the diameter of over $100 \mathrm{~nm}$ (Figure 3b) and nanoshells with only few layers (Figure 3c), which provide the BET surface area of up to $\sim 870 \mathrm{~m}^{2} \mathrm{~g}^{-1}$ by $\mathrm{N}_{2}$ adsorption and electrochemically accessible surface area $\left(\sim 450 \mathrm{~m}^{2} \mathrm{~g}^{-1}\right)$ deduced with the gravimetric double layer capacitance. This structure provides numerous large channels for mass transfer and catalyst loading sites due to the high $\mathrm{N}$ concentration on the CNTs surfaces [77]. More importantly, this N-CNTs, or graphene tubes, significantly prevent the catalytic nanoparticles from agglomeration, showing almost no morphology changes after ADT (Figure 3d-3f) [78]. The 3D structural materials also facilitate the formation of porous channels for mass transfer $[66,67]$, and can be packaged facilely or used as the catalyst layer directly [70]. 

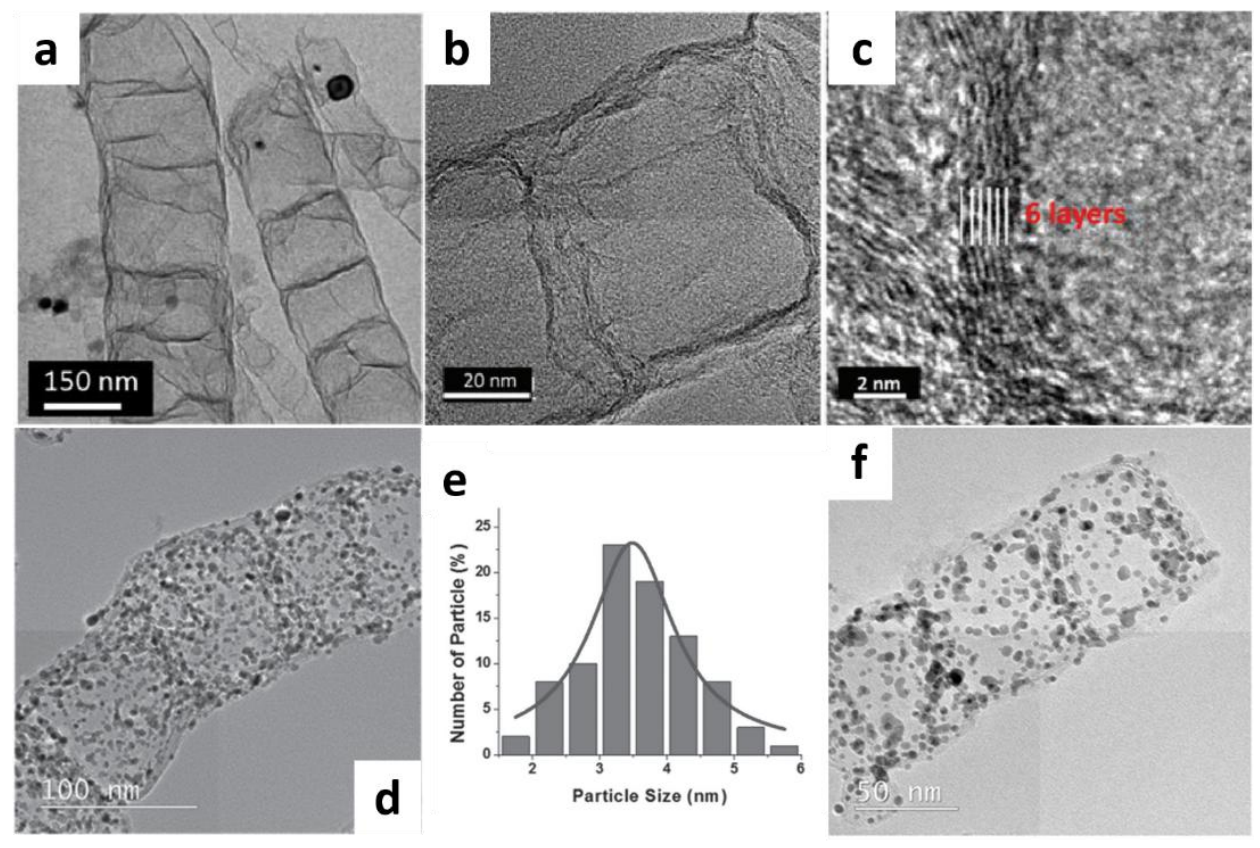

Figure 3 (a,b) TEM and (c) HR-TEM images of carbon nanotubes synthesized using Fe precursor, revealing the subtle structures of carbon nanotubes and nanoshells. Reproduced with permission from ref. [77]. Copyright (2015) Royal Society of Chemistry; (d) TEM image and (e) particle size distribution in the of $20 \mathrm{wt} \% \mathrm{Pt} / \mathrm{N}$-doped graphene tube catalysts and (f) TEM images of Pt/ $\mathrm{N}$ doped graphene tube after 5,000 potential cycles (between 0.6 and $1.1 \mathrm{~V}$, scanning rate: $50 \mathrm{mV} / \mathrm{s}$ ). Reprinted with permission from ref. [78]. Copyright (2014) John Wiley \& Sons, Inc.

\section{Non-carbon supports}

There has been considerable progress in non-carbon supports [33,36]. General properties of non-carbon support (mainly ceramic materials) include corrosion-resistance, potential strong metal-support interaction, and stable porous structure, but these materials suffer from low electrical conductivity and low porosity. Several types of non-carbon supports have been investigated, including titanium oxide [79-83], cerium oxide [84,85], niobium oxide [86], tungsten oxide [87-89], some carbides [90-96], nitrides [97], oxy-nitrides [98], borides [99] and conductive polymer $[100,101]$.

Titanium dioxide $\left(\mathrm{TiO}_{2}\right)$ presents high chemical and electrochemical stability, along with strong interaction with metal nanoparticles, showing great potential as an alternative support 
material for PEM fuel cells. A general observation for many non-carbon supported electrocatalysts is that they may demonstrate decent performance in half cell test (e.g., rotating disk electrode test) but fail to reproduce such performance in MEA test. The reasons for this phenomenon still need further investigation, but good MEA performance has also been reported in literatures. For example, Figure 4a gives typical polarization curves of the PEM fuel cells using $\mathrm{Pt} / \mathrm{TiO}_{2}$ and $\mathrm{Pt} / \mathrm{C}$ as electrocatalysts [80]. The $\mathrm{Pt} / \mathrm{TiO}_{2}$ presents similar performance with $\mathrm{Pt} / \mathrm{C}$, with even lower mass transfer limitation at high current density range. More significantly, the durability as shown in Figure $4 \mathrm{~b}$ and $4 \mathrm{c}$ were greatly improved [80]. The specific reasons for the good MEA performance were not provided in the literature. However, structure of $\mathrm{TiO}_{2}$ was designed to be mesoporous with the BET surface area of up to $250 \mathrm{~m}^{2} \mathrm{~g}^{-1}$ [80], which is comparable to commonly used Vulcan XC-72 carbon black [102]. This structure may facilitate mass transfer, which may mitigate the limitation caused by low electrical conductivity [80,103-105]. However, for most metal oxides, the surface area is usually lower than carbon materials $[106,107]$. Thus mesoporous metail oxides synthesized by soft-template $[108,109]$ or hard-template $[110,111]$ that present relatively high surface area should be considered. In addition, the density of $\mathrm{TiO}_{2}$ is about 2-fold higher than carbon, so that the catalyst layer consisting of $\mathrm{TiO}_{2}$ is much thinner $(3 \mu \mathrm{m})$ than the one with carbon (11 $\mu \mathrm{m})$ [80], which may lead to low mass transfer limitation. These factors should be investigated and taken into consideration in the real PEM fuel cells when the non-conductive supports are used.

When the oxygen vacancy is generated in titanium oxide, the electrical conductivity of $\mathrm{TiO}_{2}$ can be improved. For instance, the substoichiometric titanium oxide, which is quite stable against high potential up to $1.5 \mathrm{~V}$ [112], the electrical conductivity are greatly enhanced. In addition to $\mathrm{TiO}_{2}$, some other nonstoichiometric metal oxides such as $\mathrm{CeO}_{\mathrm{x}}$, $\mathrm{NbO}_{\mathrm{x}}$ etc. may also change conductivity when switching from one state to another state. However, the substoichiometric oxide is always synthesized at high temperature (e.g. $1000{ }^{\circ} \mathrm{C}$ ), resulting in severe agglomeration and low electrochemical surface area, which limit its application as support materials. Some other strategies can be used to address these 
issues. As the loading of Pt increases or with proper processing methods, the Pt nanoparticles deposited on $\mathrm{TiO}_{2}$ can contact directly with each other [104] or form a conducting $\mathrm{Pt}$ nanowire network to enhance the electrical conductivity of the electrocatalysts (Figure $4 \mathrm{~d}$ and 4e). Another solution is doping or adding some conductive oxides in titanium oxide. For example, $\mathrm{Nb}$-doped $\mathrm{TiO}_{2}$ has demonstrated high electrical conductivity similar to carbon materials [113-117]. As an extension of doping strategy, the combination of nonconductive oxide $\left(\mathrm{SiO}_{2}[118,119]\right.$ and $\mathrm{TiO}_{2}$ [27]) with conductive oxides such as $\mathrm{RuO}_{2}$ produces metal oxide composites with high conductivity and stability. The $\mathrm{RuO}_{2}-\mathrm{SiO}_{2}$ is commonly synthesized by loading $\mathrm{RuO}_{2}$ on the well-defined $\mathrm{SiO}_{2}$ template to produce the uniform nanocomposite (Figure 5a) [118]. This $\mathrm{RuO}_{2}-\mathrm{SiO}_{2}$ nanocomposite presents great conductivity, which changes with the various ratios of the two oxides (Figure 5b) [119]. This provides a new method to obtain a balanced stability and conductivity. Recently, the $\mathrm{RuO}_{2}-\mathrm{TiO}_{2}$ nanocomposite supported catalysts has been synthesized and tested in both half-cell and MEA tests. Pt nanoparticles supported on $\mathrm{RuO}_{2}$ and $\mathrm{TiO}_{2}$ exhibit excellent stability in comparison with Pt supported on carbon [27]. Still, the high cost of $\mathrm{RuO}_{2}$ might be a concern.
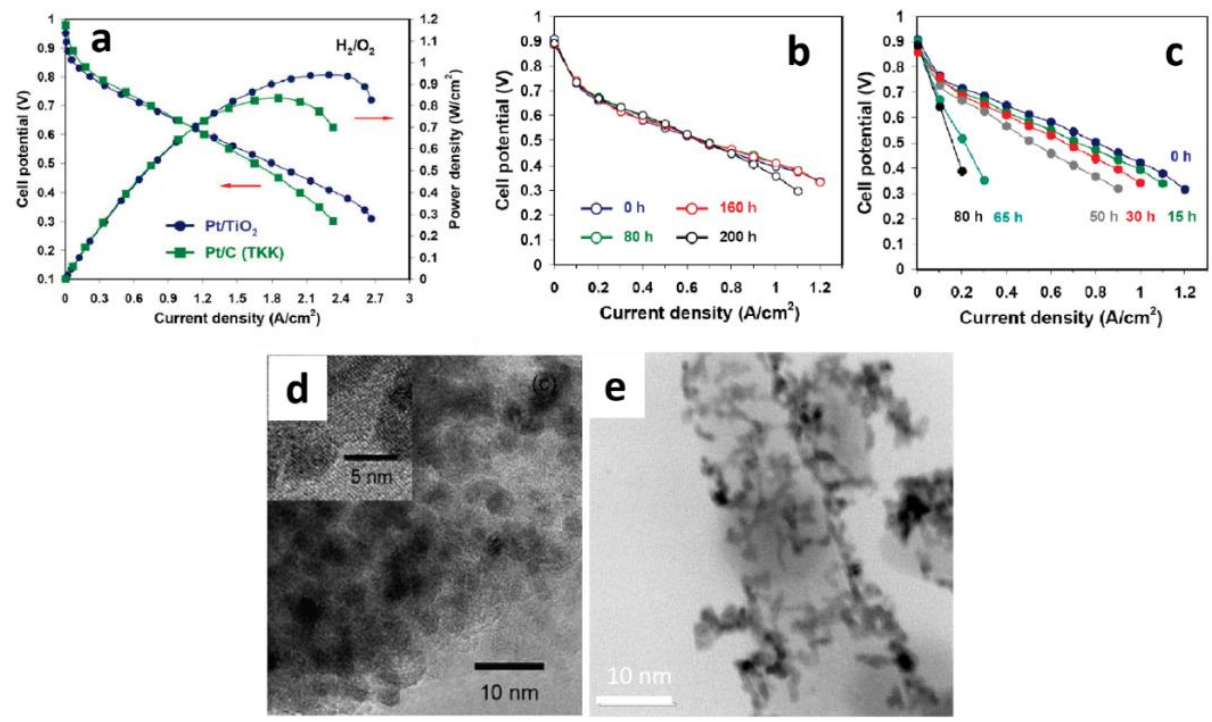

Figure 4. (a) The polarization curves for $\mathrm{PEM}$ fuel cells using the $\mathrm{Pt} / \mathrm{TiO}_{2}$ and $\mathrm{Pt} / \mathrm{C}$ electrocatalysts; the polarization curves for PEM fuel cells with (b) $\mathrm{Pt} / \mathrm{TiO}_{2}$ and (c) $\mathrm{Pt} / \mathrm{C}$ electrocatalysts after ADT. Figures are taken with permission from ref. [80]. Copyright (2009) American Chemical Society; (d) TEM image of 60 wt\% Pt on mesoporous $\mathrm{TiO}_{2}$. Reproduced with permission from ref. [104]. Copyright (2011) Elsevier; (e) 
TEM image of the Pt nanowires on $\mathrm{TiO}_{2}$ nanorods.
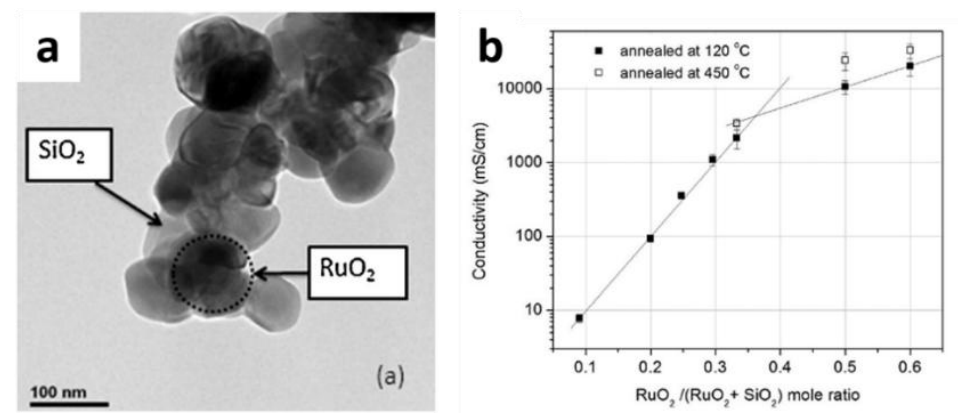

Figure 5. (a) TEM image of $\mathrm{RuO}_{2}-\mathrm{SiO}_{2}$ (1:1) support nanocomposite, reproduced with permission from ref. [118]. Copyright (2013) Elsevier; (b) electrical conductivity of $\mathrm{RuO}_{2}-\mathrm{SiO}_{2}$ nanocomposite annealed at 120 and $450{ }^{\circ} \mathrm{C}$ with different ratios. Reproduced with permission from ref. [119]. Copyright (2012) American Chemical Society.

The surface chemistry of metal oxides can be tuned to provide additional functions for fuel cell applications. Taking cerium dioxide $\left(\mathrm{CeO}_{\mathrm{x}}\right)$ as an example, it can capture or release electron and facilitate electron transfer between the $\mathrm{Ce}^{3+}$ and $\mathrm{Ce}^{4+}$ states $[120,121]$. This characteristic makes it possible for $\mathrm{CeO}_{\mathrm{x}}$ to tune the functional groups on the surfaces, which not only protect the nanoparticles, but also reduce the aging of polymer membrane. X-ray absorption fine structure measurements have shown that $\mathrm{CeO}_{\mathrm{x}}$ layer on $\mathrm{Pt}$ nanoparticles can increase the onset oxidation potential of $\mathrm{Pt}$, where the $\mathrm{Ce}^{3+}$ is oxidized into $\mathrm{Ce}^{4+}$ [84]. Similarly, the $\mathrm{Ce}^{3+}$ may reduce the harmful free radical $\mathrm{OH}^{*}$ to less reactive $\mathrm{OOH}^{*}$ which can prevent the membrane from the attack by the free radical [122-124]. Another function of these metal oxides is to generate some oxygen containing species to repulse the intermediates of ORR on Pt, which then improve the whole ORR activity [86,125].

For the past ten years, a group of solid whiskers, composed with an organic pigment N, $\mathrm{N}$-di(3,5-xylyl)perylene-3,4:9,10 bis(dicarboximide) (donated as perylene red), have also been employed as the support with high stability [126-131]. The perylene red arrays grow on the micro structured substrate (Figure 6a) and then are coated with elementary or multielement thin film by magnetic sputtering to form the nanostructured thin film (NSTF) catalyst electrode. The catalyst layer in MEA using this NSTF electrode can be controlled 
under $1 \mu \mathrm{m}$ (Figure 6b), which may present significantly lower mass transfer limitation (but may result in water management issue) compared with the catalyst layer with oxides as supports in Ref. [80]. The unique structure of NSTF catalyst electrode leads to much higher activity and particularly higher stability (Figure 6c).
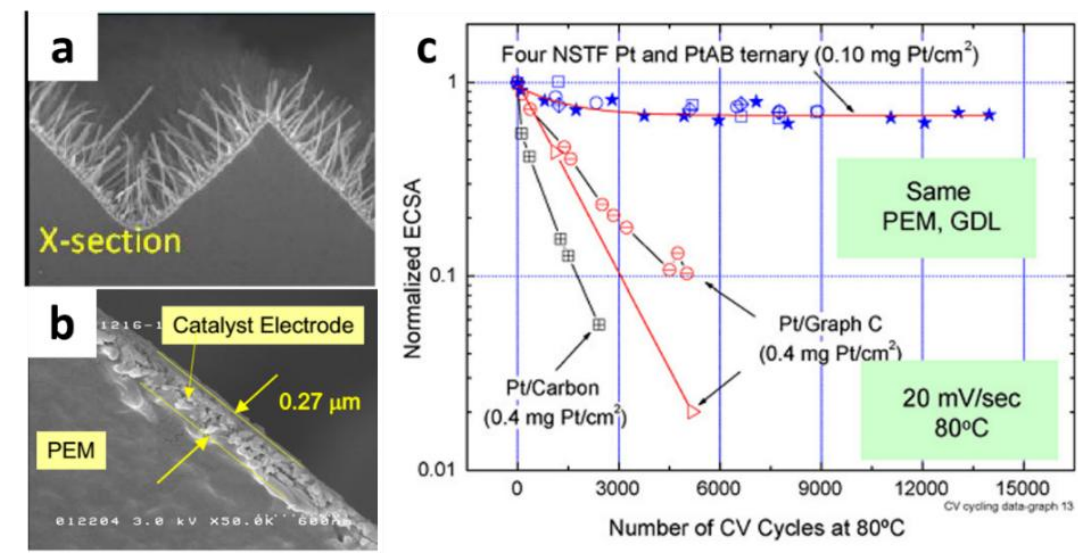

Figure 6. SEM images of (a) a monolayer of oriented NSTF catalyst support whiskers on a microstructured substrate web [126]. Copyright (2012) The Electrochemical Society; (b) the cross-section of NSTF electrode [127,129]. Copyright (2006) Elsevier; (c) normalized surface area vs. cycle number of CV from 0.6 to $1.2 \mathrm{~V}$ for a series of NSTF catalysts and Pt on carbon catalysts (the solid star symbols were pure $\mathrm{Pt}$ at $0.15 \mathrm{mg} \mathrm{cm}^{-2}$ loading, the open squares were pure $\mathrm{Pt}$ at $0.10 \mathrm{mg} \mathrm{cm}^{-2}$ loading, the open circles were $\mathrm{Pt}_{49} \mathrm{Co}_{26} \mathrm{Mn}_{25}$ with $0.10 \mathrm{mg} \mathrm{Pt} \mathrm{cm}{ }^{-2}$, and the diamond-plus symbols were $\mathrm{Pt}_{69} \mathrm{Co}_{28} \mathrm{Mn}_{3}$ also with 0.10 $\mathrm{mg} \mathrm{Pt} \mathrm{cm}{ }^{-2}$. All MEAs used the same 3M ionomer PEM and GDL. The initial mass specific surface areas for the Pt/carbon, Pt/graph C, and NSTF catalysts were 192, 147, and $10 \mathrm{~m}^{2} \mathrm{~g}_{\mathrm{Pt}}^{-1}$, respectively.) [129]. Copyright (2006) Elsevier.

\section{Hybrid carbon-metal oxide nanocomposites}

The concept of using hybrid carbon-metal oxide nanocomposites as catalyst support takes advantage of both carbon and stable metal oxides: i) metal oxides are more stable than carbon and can protect carbon materials from corrosion [35,36]; ii) metal oxides may stabilize metal catalyst through strong metal-support interaction [132-134]; iii) metal oxides are usually hydrophilic and may assist in water management [36,104,113]; iv) carbon is highly conductive, highly porous and has high surface area [31,34,39,71]. Since abundant 
knowledge and experiences have been obtained from carbon based electrocatalysts for PEM fuel cells, the use of hybrid carbon-metal oxide nanocomposites makes it possible to leverage this knowledge and experience, which will accelerate the process of moving materials development from laboratory to practical devices.

The development of hybrid carbon-metal oxide nanocomposites is still at its early stage. Fundamental studies like the understanding of structure-property relationship are critical to the design of better-performing materials. In order to do this, good model systems are very helpful, among which is graphene as a substrate. Indium tin oxide (ITO) was uniformly coated on graphene, followed by Pt nanoparticle coating [134]. The uniformly dispersed ITO nanoparticles on graphene were found to facilitate the deposition of $\mathrm{Pt}$ nanoparticles. $\mathrm{Pt}$ nanoparticles were loaded at the junction of graphene and ITO (Figure 7a and 7b). Within this special nanostructure, the Pt nanoparticles contact directly with both carbon substrate (graphene) and metal oxide (ITO). This provides a good model system to study the interaction between $\mathrm{Pt}$, metal oxide and carbon, and their relationship with performance. Through a systematic investigation, the strong interaction between ITO and Pt nanoparticles, the efficient protection for graphene substrate (by metal oxide) and the long-range conductivity enabled by graphene substrate collectively lead to enhanced activity and durability. This concept may provide a new approach to develop alternative catalyst support.
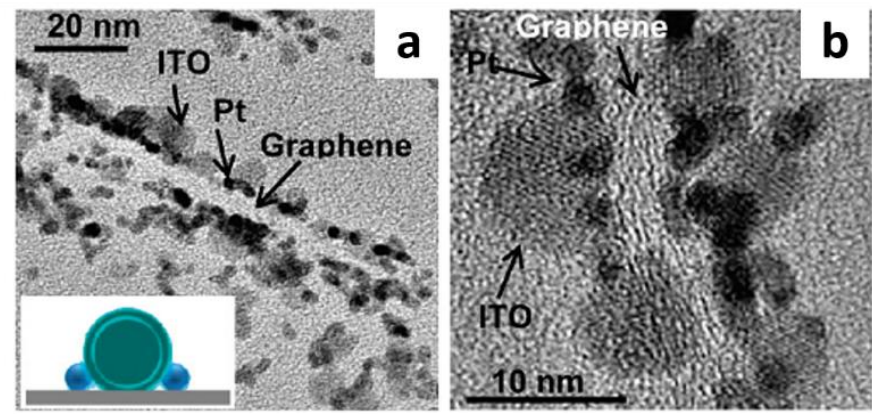

Figure 7. $(a, b)$ The TEM images of Pt deposited on the composite of ITO and graphene (insert is the schematic structure of Pt-ITO-graphene nanocomposite). Reprinted with permission from ref. [134]. Copyright (2011) American Chemical Society.

Although graphene is a good model system for structure-property relationship study, the 
2D structure may have limitation in real PEM fuel cells. 2D graphene sheets tend to be horizontally stacked, which decreases the porosity and increases tortuosity. This can lead to significant problems in terms of triple-phase boundary formation and mass transfer [66]. In this regard, other carbon materials such as carbon black [125,135-139], carbon nanotubes [132,140-146], carbonized carbon [147,148] etc. may be used. An in-situ carbonization method was developed to strengthen the effects of metal oxides and further anchor the deposited Pt nanoparticles on composite supports [82,83]. Initially, Pt nanoparticles were deposited at the $\mathrm{TiO}_{2}$-carbon composite support, which was further coated by carbon precursor. The melted carbon precusor stay at the interfaces of Pt nanoparticles and $\mathrm{TiO}_{2}$-carbon composite support, and was then carbonized to form a stable but incomplete carbon layer on $\mathrm{Pt}-\mathrm{TiO}_{2}$-carbon. In this way, $\mathrm{Pt}$ nanoparticles were anchored and stabilized (Figure 8a). The electrochemical surface area of this carbon riveted $\mathrm{Pt}-\mathrm{C}-\mathrm{TiO}_{2}$ catalyst was calculated to be $72.66 \mathrm{~m}^{2} \mathrm{~g}_{\mathrm{Pt}}^{-1}$, which is similar to Pt/C $\left(81.54 \mathrm{~m}^{2} \mathrm{~g}_{\mathrm{Pt}}^{-1}\right)$ and the as-prepared Pt-C-TiO $2\left(79.91 \mathrm{~m}^{2} \mathrm{~g}^{-1}{ }_{\mathrm{Pt}}\right)$ catalysts [82], indicating that the carbonization can block only few active sites due to the incomplete carbon layer. Figure $8 \mathrm{~b}$ and $8 \mathrm{c}$ give typical TEM images of this catalyst before and after the ADT, respectively. The size of Pt nanoaparticles increases slightly by less than $1 \mathrm{~nm}$ and the electrocatalyst maintains original structure after ADT. In contrast, the average size of catalysts without anchoring presents a sharply growth by 1.69 $\mathrm{nm}$. This strategy can also be applied in $\mathrm{Pt} / \mathrm{TiO}_{2} / \mathrm{CNT}$ nanocomposites [83].

a

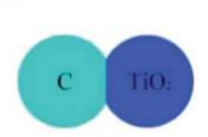

(1)

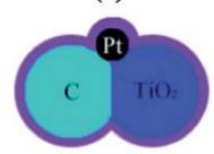

(3)

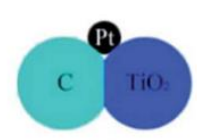

(2)

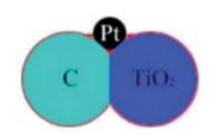

(4)
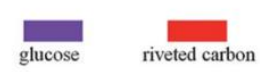
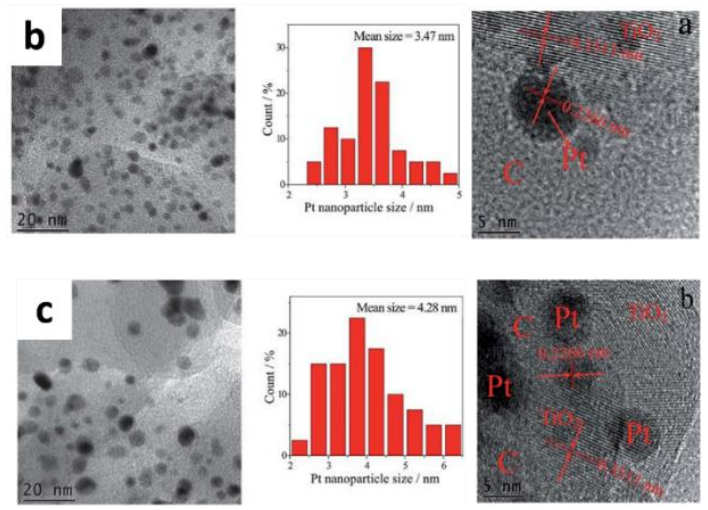

Figure 8. (a) Schematic illustration of the preparation of carbonization stabilized catalyst: (1) mixed 
support, (2) as prepared Pt-C-TiO ${ }_{2}$, (3) glucose coating Pt-C-TiO ${ }_{2}$, (4) carbon riveted Pt-C-TiO ${ }_{2}$; the TEM, size distribution and HRTEM images of carbon riveted $\mathrm{Pt} / \mathrm{TiO}_{2} / \mathrm{C}$ catalyst (b) before and (c) after ADT. Reproduced with permission from ref. [82]. Copyright (2010) Royal Society of Chemistry.

Recently, a new method, area-selective atomic layer deposition (ALD), was developed to coat metal oxides onto catalyst to stabilize Pt nanoparticles on carbon nanotubes. Different from other methods, metal oxides were applied after Pt was loaded onto carbon support. For example, Pt nanoparticles were deposited on N-doped CNTs by ALD followed by treatment with strongly adsorptive oleylamine as blocking agent in order to prevent zirconia from depositing onto Pt surfaces during the following steps. As a result, the zirconia was deposited around Pt nanoparticles to form nanocages by ALD [149]. This encapsulation not only stabilizes Pt nanoparticles, but also provides porous structure for mass transfer.

The improved performance of electrocatalysts with hybrid nanocomposites of metal oxides-carbon shows the potential of this kind of support materials in PEM fuel cells. However, most of today's research results are from half-cell test. Further effort is needed to apply the hybrid nanocomposite support into real PEM fuel cell.

\section{Perspective}

Catalyst support plays critical roles in PEM fuel cell performance and durability. The corrosion of supports in electrocatalysts leads to the degradation of PEM fuel cell electrocatalysts. It also causes the changes of electrode structure, including porosity and surface chemistry, which affects mass transfer and water management.

Porous carbon black remains the most widely-used catalyst support in today's technology. New carbon materials such as CNTs, graphene, mesoporous carbon, graphite nanopallete, "solid core type support" and their composites are under investigation for PEM fuel cells. Good progress has also been made on non-carbon support (metal oxides) and metal oxide-carbon composites. However, there are still gaps and challenges between the properties of today's materials and practical application requirements. First of all, most metal oxides present poor electrical conductivity. Possible solutions such as doping and/or mixing with 
other conductive metal oxides (but usually precious metal) can be adopted to increase the conductivity. In carbon-metal oxide composite, carbon can provide the long-range conductivity if catalytic metal (alloy), metal oxides and carbon form special structure such as the so-called "triple-junctions". However, a systematic study is needed in terms of the choice of metal oxides, synthesis of desired structures, and processing approaches to integrate catalyst in devices. Secondly, the novel support materials, including non-carbon and carbon-metal oxides composite need to be evaluated in MEA. Due to the complex working condition (e.g., heat and water management, interfaces between components), MEAs using non-carbon (maybe hybrids also) show undesired performance. The materials processing and MEA fabrication may need to be reinvented. In terms of structure-property understanding, advanced tools (in-situ characterizations, simulations) need to be developed, in particular for understanding complex problems such as how electrocatalysts interact with other components and how the interface degrades. When decreasing Pt loading in fuel cell, it presents more challenges for electrocatalysts because some new issues may emerge [150]. Researchers on catalysts and catalyst supports should look beyond traditional boundaries and interact more with those from component integration and device fabrication, applications.

\section{Acknowledgment}

This work is supported by the U.S. Department of Energy's (DOE's) Office of Energy Efficiency and Renewable Energy Fuel Cell Technologies Office. L. Du acknowledges the scholarship from the China Scholarship Council. PNNL is operated by Battelle for DOE under Contract DE-AC05-76L01830.

\section{References}

[1] A.Z. Weber, J. Newman, Chem. Rev., 104 (2004) 4679-4726.

[2] M. Winter, R.J. Brodd, Chem. Rev., 104 (2004) 4245-4270.

[3] M.K. Debe, Nature, 486 (2012) 43-51. 
[4] S. Cherevko, N. Kulyk, K.J.J. Mayrhofer, Nano Energy, (2016) DOI: 10.1016/j.nanoen.2016.03.005.

[5] Y. Shao, G. Yin, Y. Gao, P. Shi, J. Electrochem. Soc., 153 (2006) A1093-A1097.

[6] Y. Shao, G. Yin, Y. Gao, J. Power Sources, 171 (2007) 558-566.

[7] M.C. Smith, J.A. Gilbert, J.R. Mawdsley, S. Seifert, D.J. Myers, J. Am. Chem. Soc., 130 (2008) 8112-8113.

[8] P. Trogadas, J. Parrondo, F. Mijangos, V. Ramani, J. Mater. Chem., 21 (2011) 19381-19388.

[9] M.P. Rodgers, L.J. Bonville, R. Mukundan, R.L. Borup, R. Ahluwalia, P. Beattie, R.P. Brooker, N. Mohajeri, H.R. Kunz, D.K. Slattery, J.M. Fenton, ECS Trans., 58 (2013) $129-148$.

[10] K.J.J. Mayrhofer, S.J. Ashton, J.C. Meier, G.K.H. Wiberg, M. Hanzlik, M. Arenz, J. Power Sources, 185 (2008) 734-739.

[11] K. Hartl, M. Hanzlik, M. Arenz, Energy Environ. Sci., 4 (2011) 234-238.

[12] J.C. Meier, C. Galeano, I. Katsounaros, A.A. Topalov, A. Kostka, F. Schüth, K.J.J. Mayrhofer, ACS Catal., 2 (2012) 832-843.

[13] J.C. Meier, I. Katsounaros, C. Galeano, H.J. Bongard, A.A. Topalov, A. Kostka, A. Karschin, F. Schüth, K.J.J. Mayrhofer, Energy Environ. Sci., 5 (2012) 9319-9330.

[14] K. Yu, D.J. Groom, X. Wang, Z. Yang, M. Gummalla, S.C. Ball, D.J. Myers, P.J. Ferreira, 
Chem. Mater., 26 (2014) 5540-5548.

[15] P. Strasser, S. Kühl, Nano Energy, under review.

[16] H. Lv, D. Li, Y. Kang, D. Strmcnik, N.M. Markovic, V.R. Stamenkovic, Nano Energy, under review.

[17] J. Herranz, J. Durst, E. Fabbri, A. Patru, X. Cheng, A.A. Permyakova, T.J. Schmidt, Nano Energy, (2016) DOI: 10.1016/j.nanoen.2016.01.027.

[18] A.S. Arico, P. Bruce, B. Scrosati, J.M. Tarascon, W. van Schalkwijk, Nat. Mater., 4 (2005) 366-377.

[19] G. Wu, P. Zelenay, Acc. Chem. Res., 46 (2013) 1878-1889.

[20] S. Guo, S. Zhang, S. Sun, Angew. Chem., Int. Ed., 52 (2013) 8526-8544.

[21] D. Deng, L. Yu, X. Chen, G. Wang, L. Jin, X. Pan, J. Deng, G. Sun, X. Bao, Angew. Chem., Int. Ed., 52 (2013) 371-375.

[22] J. Wu, H. Yang, Acc. Chem. Res., 46 (2013) 1848-1857.

[23] I. Katsounaros, S. Cherevko, A.R. Zeradjanin, K.J. Mayrhofer, Angew. Chem., Int. Ed., 53 (2014) 102-121.

[24] C.A. Reiser, L. Bregoli, T.W. Patterson, J.S. Yi, J.D. Yang, M.L. Perry, T.D. Jarvi, Electrochem. Solid-State Lett., 8 (2005) A273-A276

[25] A.A. Franco, M. Guinard, B. Barthe, O. Lemaire, Electrochim. Acta, 54 (2009) $5267-5279$. 
[26] P.T. Yu, W. Gu, R. Makharia, F.T. Wagner, H.A. Gasteiger, ECS Trans., 3 (2006) 797-809.

[27] J. Parrondo, T. Han, E. Niangar, C. Wang, N. Dale, K. Adjemian, V. Ramani, Proc. Natl. Acad. Sci. U.S.A., 111 (2014) 45-50.

[28] Y. Yu, H. Li, H. Wang, X.-Z. Yuan, G. Wang, M. Pan, J. Power Sources, 205 (2012) $10-23$.

[29] A. Lamibrac, G. Maranzana, O. Lottin, J. Dillet, J. Mainka, S. Didierjean, A. Thomas, C. Moyne, J. Power Sources, 196 (2011) 9451-9458.

[30] B.C. Steele, A. Heinzel, Nature, 414 (2001) 345-352.

[31] P. Serp, Appl. Catal., A, 253 (2003) 337-358.

[32] R. Borup, J. Meyers, B. Pivovar, Y.S. Kim, R. Mukundan, N. Garland, D. Myers, M. Wilson, F. Garzon, D. Wood, P. Zelenay, K. More, K. Stroh, T. Zawodzinski, J. Boncella, J.E. McGrath, M. Inaba, K. Miyatake, M. Hori, K. Ota, Z. Ogumi, S. Miyata, A. Nishikata, Z. Siroma, Y. Uchimoto, K. Yasuda, K. Kimijima, N. Iwashita, Chem. Rev., 107 (2007) 3904-3951.

[33] Y. Shao, J. Liu, Y. Wang, Y. Lin, J. Mater. Chem., 19 (2009) 46-59.

[34] E. Antolini, Appl. Catal., B, 88 (2009) 1-24.

[35] E. Antolini, Appl. Catal., B, 100 (2010) 413-426.

[36] Y.J. Wang, D.P. Wilkinson, J. Zhang, Chem. Rev., 111 (2011) 7625-7651. 
[37] M. Pumera, Chem. Soc. Rev., 39 (2010) 4146-4157.

[38] A. Rabis, P. Rodriguez, T.J. Schmidt, ACS Catal., 2 (2012) 864-890.

[39] J. Tang, J. Liu, N.L. Torad, T. Kimura, Y. Yamauchi, Nano Today, 9 (2014) 305-323.

[40] Y. Shao, Y. Cheng, W. Duan, W. Wang, Y. Lin, Y. Wang, J. Liu, ACS Catal., 5 (2015) 7288-7298.

[41] D. Higgins, P. Zamani, A. Yu, Z. Chen, Energy Environ. Sci., 9 (2016) 357-390.

[42] W. Zhang, P. Sherrell, A.I. Minett, J.M. Razal, J. Chen, Energy Environ. Sci., 3 (2010) $1286-1293$.

[43] R. Borup, DOE 2014 Annual Merit Review Meeting, (2014) https://www.hydrogen.energy.gov/pdfs/review14/fc013_borup_2014_o.pdf.

[44] U.S.D.F.C.T. Team, http://www.uscar.org/, AcceleratedTesting and Polarization Curve Protocols for PEM Fuel Cells.

[45] R.L. Borup, D.D. Papadias, R. Mukundan, D. Spernjak, D.A. Langlois, R. Ahluwalia, K.L. More, S. Grot, ECS Trans., 69 (2015) 1029-1038.

[46] K.L. More, DOE 2013 Annual Merit Review Meeting, (2013) https://www.hydrogen.energy.gov/pdfs/review13/fc020_more_2013_o.pdf.

[47] K.L. More, DOE 2014 Annual Merit Review Meeting, (2014) https://www.hydrogen.energy.gov/pdfs/review14/fc020_more_2014_o.pdf.

[48] M. Arenz, A. Zana, Nano Energy, under review. 
[49] Y. Shao, G. Yin, J. Wang, Y. Gao, P. Shi, J. Power Sources, 161 (2006) 47-53.

[50] W. Yang, X. Wang, F. Yang, C. Yang, X. Yang, Adv. Mater., 20 (2008) 2579-2587.

[51] S.W. Lee, B.S. Kim, S. Chen, Y. Shao-Horn, P.T. Hammond, J. Am. Chem. Soc., 131 (2009) 671-679.

[52] L. Hu, D.S. Hecht, G. Gruner, Chem. Rev., 110 (2010) 5790-5844.

[53] W. Xiong, F. Du, Y. Liu, A. Perez, Jr., M. Supp, T.S. Ramakrishnan, L. Dai, L. Jiang, J. Am. Chem. Soc., 132 (2010) 15839-15841.

[54] S. Zhang, Y. Shao, G. Yin, Y. Lin, J. Mater. Chem., 20 (2010) 2826-2830.

[55] S. Zhang, Y. Shao, G. Yin, Y. Lin, Appl. Catal., B, 102 (2011) 372-377.

[56] T. Shu, S.-J. Liao, C.-T. Hsieh, A.K. Roy, Y.-Y. Liu, D.-Y. Tzou, W.-Y. Chen, Electrochim. Acta, 75 (2012) 101-107.

[57] Z. Yang, M.R. Berber, N. Nakashima, Electrochim. Acta, 170 (2015) 1-8.

[58] K. Parvez, S. Yang, Y. Hernandez, A. Winter, A. Turchanin, X. Feng, K. Mullen, ACS Nano, 6 (2012) 9541-9550.

[59] S. Guo, S. Sun, J. Am. Chem. Soc., 134 (2012) 2492-2495.

[60] S. Zhang, Y. Shao, H. Liao, M.H. Engelhard, G. Yin, Y. Lin, ACS Nano, 5 (2011) $1785-1791$

[61] Z. Yang, I. Moriguchi, N. Nakashima, ACS Appl. Mater. Interfaces, 7 (2015) 9800-9806.

[62] B. Fang, J.H. Kim, C. Lee, J.S. Yu, J Phys Chem C, 112 (2008) 639-645. 
[63] C. Baldizzone, S. Mezzavilla, H.W. Carvalho, J.C. Meier, A.K. Schuppert, M. Heggen, C. Galeano, J.D. Grunwaldt, F. Schuth, K.J. Mayrhofer, Angew. Chem., Int. Ed., 53 (2014) $14250-14254$.

[64] F. Hasché, T.-P. Fellinger, M. Oezaslan, J.P. Paraknowitsch, M. Antonietti, P. Strasser, ChemCatChem, 4 (2012) 479-483.

[65] Y. Li, Y. Li, E. Zhu, T. McLouth, C.Y. Chiu, X. Huang, Y. Huang, J. Am. Chem. Soc., 134 (2012) 12326-12329.

[66] S. Park, Y. Shao, H. Wan, P.C. Rieke, V.V. Viswanathan, S.A. Towne, L.V. Saraf, J. Liu, Y. Lin, Y. Wang, Electrochem. Commun., 13 (2011) 258-261.

[67] D. He, K. Cheng, T. Peng, M. Pan, S. Mu, J. Mater. Chem. A, 1 (2013) 2126-2132.

[68] P. Ramesh, M.E. Itkis, J.M. Tang, R.C. Haddon, J. Phys. Chem. C, 112 (2008) 9089-9094.

[69] R.W. Chen, J. Yan, Y. Liu, J.H. Li, J. Phys. Chem. C, 119 (2015) 8032-8037.

[70] S.L. Zhao, H.J. Yin, L. Du, G.P. Yin, Z.Y. Tang, S.Q. Liu, J. Mater. Chem. A, 2 (2014) $3719-3724$.

[71] S.H. Joo, S.J. Choi, I. Oh, J. Kwak, Z. Liu, O. Terasaki, R. Ryoo, Nature, 412 (2001) $169-172$.

[72] B.Z. Fang, J.H. Kim, M. Kim, J.S. Yu, Chem. Mater., 21 (2009) 789-796.

[73] H.Z. Geng, K.K. Kim, K.P. So, Y.S. Lee, Y. Chang, Y.H. Lee, J. Am. Chem. Soc., 129 
(2007) 7758-7759.

[74] F. Zaragoza-Martín, D. Sopeña-Escario, E. Morallón, C.S.-M. de Lecea, J. Power Sources, 171 (2007) 302-309.

[75] S. Pylypenko, A. Borisevich, K.L. More, A.R. Corpuz, T. Holme, A.A. Dameron, T.S. Olson, H.N. Dinh, T. Gennett, R. O'Hayre, Energy Environ. Sci., 6 (2013) 2957-2964.

[76] T. Yoshida, K. Kojima, Electrochem. Soc. Interface, 24 (2015) 45-49.

[77] X. Wang, Q. Li, H. Pan, Y. Lin, Y. Ke, H. Sheng, M.T. Swihart, G. Wu, Nanoscale, 7 (2015) 20290-20298.

[78] Q. Li, H. Pan, D. Higgins, R. Cao, G. Zhang, H. Lv, K. Wu, J. Cho, G. Wu, Small, 11 (2015) 1443-1452.

[79] G. Wu, M.A. Nelson, N.H. Mack, S. Ma, P. Sekhar, F.H. Garzon, P. Zelenay, Chem. Commun., 46 (2010) 7489-7491.

[80] S.Y. Huang, P. Ganesan, S. Park, B.N. Popov, J. Am. Chem. Soc., 131 (2009) 13898-13899.

[81] B. Hasa, E. Kalamaras, E.I. Papaioannou, J. Vakros, L. Sygellou, A. Katsaounis, Electrochim. Acta, 179 (2015) 578-587.

[82] Z.-Z. Jiang, Z.-B. Wang, Y.-Y. Chu, D.-M. Gu, G.-P. Yin, Energy Environ. Sci., 4 (2011) 728-735.

[83] Z.-Z. Jiang, Z.-B. Wang, Y.-Y. Chu, D.-M. Gu, G.-P. Yin, Energy Environ. Sci., 4 (2011) 
$2558-2566$.

[84] T. Masuda, H. Fukumitsu, K. Fugane, H. Togasaki, D. Matsumura, K. Tamura, Y. Nishihata, H. Yoshikawa, K. Kobayashi, T. Mori, K. Uosaki, J. Phys. Chem. C, 116 (2012) 10098-10102.

[85] Y.Y. Chu, Z.B. Wang, Z.Z. Jiang, D.M. Gu, G.P. Yin, Adv. Mater., 23 (2011) 3100-3104.

[86] K. Sasaki, L. Zhang, R.R. Adzic, Phys. Chem. Chem. Phys., 10 (2008) 159-167.

[87] Y. Lu, Y. Jiang, X. Gao, X. Wang, W. Chen, J. Am. Chem. Soc., 136 (2014) $11687-11697$.

[88] M.S. Saha, M.N. Banis, Y. Zhang, R.Y. Li, X.L. Sun, M. Cai, F.T. Wagner, J. Power Sources, 192 (2009) 330-335.

[89] Z. Zhang, X. Wang, Z. Cui, C. Liu, T. Lu, W. Xing, J. Power Sources, 185 (2008) 941-945.

[90] H. Chhina, S. Campbell, O. Kesler, J. Power Sources, 179 (2008) 50-59.

[91] R.E. Fuentes, H.R. Colon-Mercado, M.J. Martinez-Rodriguez, J. Electrochem. Soc., 161 (2013) F77-F82.

[92] N.R. Elezovic, B.M. Babic, P. Ercius, V.R. Radmilovic, L.M. Vracar, N.V. Krstajic, Appl.

Catal., B, 125 (2012) 390-397.

[93] W. Zhu, A. Ignaszak, C. Song, R. Baker, R. Hui, J. Zhang, F. Nan, G. Botton, S. Ye, S. Campbell, Electrochim. Acta, 61 (2012) 198-206. 
[94] D.V. Esposito, J.G. Chen, Energy Environ. Sci., 4 (2011) 3900-3912.

[95] S.N. Stamatin, J. Speder, R. Dhiman, M. Arenz, E.M. Skou, ACS Appl. Mater. Interfaces, 7 (2015) 6153-6161.

[96] G. Cui, P.K. Shen, H. Meng, J. Zhao, G. Wu, J. Power Sources, 196 (2011) 6125-6130.

[97] B. Avasarala, T. Murray, W.Z. Li, P. Haldar, J. Mater. Chem., 19 (2009) 1803-1805.

[98] A. Seifitokaldani, O. Savadogo, Electrochim. Acta, 167 (2015) 237-245.

[99] S. Yin, S. Mu, H. Lv, N. Cheng, M. Pan, Z. Fu, Appl. Catal., B, 93 (2010) 233-240.

[100] Z. Chen, L. Xu, W. Li, M. Waje, Y. Yan, Nanotechnology, 17 (2006) 5254-5259.

[101] J. Li, X. Lin, J. Electrochem. Soc., 154 (2007) B1074-B1079.

[102] J. Wang, G. Yin, Y. Shao, S. Zhang, Z. Wang, Y. Gao, J. Power Sources, 171 (2007) 331-339.

[103] S.-Y. Huang, P. Ganesan, B.N. Popov, ACS Catal., 2 (2012) 825-831.

[104] S.-Y. Huang, P. Ganesan, B.N. Popov, Appl. Catal., B, 102 (2011) 71-77.

[105] P. Zhang, S.Y. Huang, B.N. Popov, J. Electrochem. Soc., 157 (2010) B1163-B1172.

[106] W. Li, Z. Wu, J. Wang, A.A. Elzatahry, D. Zhao, Chem. Mater., 26 (2014) 287-298.

[107] Y. Ren, Z. Ma, P.G. Bruce, Chem. Soc. Rev., 41 (2012) 4909-4927.

[108] Z. Jin, M. Xiao, Z. Bao, P. Wang, J. Wang, Angew. Chem., Int. Ed., 51 (2012) 6406-6410. 
[109] D. Chen, L. Cao, F. Huang, P. Imperia, Y.B. Cheng, R.A. Caruso, J. Am. Chem. Soc., 132 (2010) 4438-4444.

[110] W. Yue, W. Zhou, Prog. Nat. Sci., 18 (2008) 1329-1338.

[111] W. Yue, C. Randorn, P.S. Attidekou, Z. Su, J.T.S. Irvine, W. Zhou, Adv. Funct. Mater., 19 (2009) 2826-2833.

[112] T. Ioroi, H. Senoh, S.-i. Yamazaki, Z. Siroma, N. Fujiwara, K. Yasuda, J. Electrochem. Soc., 155 (2008) B321-B326.

[113] S.-Y. Huang, P. Ganesan, B.N. Popov, Appl. Catal., B, 96 (2010) 224-231.

[114] A. Bauer, L. Chevallier, R. Hui, S. Cavaliere, J. Zhang, D. Jones, J. Rozière, Electrochim. Acta, 77 (2012) 1-7.

[115] Y.-J. Wang, D.P. Wilkinson, V. Neburchilov, C. Song, A. Guest, J. Zhang, J. Mater. Chem. A, 2 (2014) 12681-12685.

[116] K. Senevirathne, V. Neburchilov, V. Alzate, R. Baker, R. Neagu, J. Zhang, S. Campbell, S. Ye, J. Power Sources, 220 (2012) 1-9.

[117] P. Ganesan, S. Huang, B.N. Popov, ECS Trans., 16 (2008) 1143-1150.

[118] A. Kumar, V.K. Ramani, Appl. Catal., B, 138-139 (2013) 43-50.

[119] C.P. Lo, V. Ramani, ACS Appl. Mater. Interfaces, 4 (2012) 6109-6116.

[120] Q. Tan, C. Du, Y. Sun, L. Du, G. Yin, Y. Gao, J. Power Sources, 263 (2014) 310-314.

[121] Q. Tan, C. Du, Y. Sun, L. Du, G. Yin, Y. Gao, Nanoscale, 7 (2015) 13656-13662. 
[122] P. Trogadas, J. Parrondo, V. Ramani, Chem. Commun., 47 (2011) 11549-11551.

[123] P. Trogadas, J. Parrondo, V. Ramani, ACS Appl. Mater. Interfaces, 4 (2012) 5098-5102.

[124] M. Lei, Z.B. Wang, J.S. Li, H.L. Tang, W.J. Liu, Y.G. Wang, Sci. Rep., 4 (2014) 7415(1)-7415(6).

[125] N. Zhang, S. Zhang, C. Du, Z. Wang, Y. Shao, F. Kong, Y. Lin, G. Yin, Electrochim. Acta, 117 (2014) 413-419.

[126] M.K. Debe, ECS Trans., 45 (2012) 47-68.

[127] M.K. Debe, DOE 2004 Annual Merit Review Meeting, (2004) https://www.hydrogen.energy.gov/pdfs/review04/fc_4_debe.pdf.

[128] M.K. Debe, DOE 2012 Annual Merit Review Meeting, (2012) https://www.hydrogen.energy.gov/pdfs/review12/fc001_debe_2012_o.pdf.

[129] M.K. Debe, A.K. Schmoeckel, G.D. Vernstrom, R. Atanasoski, J. Power Sources, 161 (2006) 1002-1011.

[130] L. Gancs, T. Kobayashi, M.K. Debe, R. Atanasoski, A. Wieckowski, Chem. Mater., 20 (2008) 2444-2454.

[131] D.F. van der Vliet, C. Wang, D. Tripkovic, D. Strmcnik, X.F. Zhang, M.K. Debe, R.T. Atanasoski, N.M. Markovic, V.R. Stamenkovic, Nat. Mater., 11 (2012) 1051-1058.

[132] L. Zhang, L.Y. Wang, C.M.B. Holt, B. Zahiri, Z. Li, K. Malek, T. Navessin, M.H. Eikerling, D. Mitlin, Energy Environ. Sci., 5 (2012) 6156-6172. 
[133] Y.T. Qu, Y.Z. Gao, F.D. Kong, S. Zhang, L. Du, G.P. Yin, Int. J. Hydrogen Energy, 38 (2013) 12310-12317.

[134] R. Kou, Y. Shao, D. Mei, Z. Nie, D. Wang, C. Wang, V.V. Viswanathan, S. Park, I.A. Aksay, Y. Lin, Y. Wang, J. Liu, J. Am. Chem. Soc., 133 (2011) 2541-2547.

[135] M. Takahashi, T. Mori, A. Vinu, H. Kobayashi, J. Drennan, D.-R. Ou, J. Mater. Res., 21 (2011) 2314-2322.

[136] D.R. Ou, T. Mori, H. Togasaki, M. Takahashi, F. Ye, J. Drennan, Langmuir, 27 (2011) 3859-3866.

[137] K. Fugane, T. Mori, D.R. Ou, A. Suzuki, H. Yoshikawa, T. Masuda, K. Uosaki, Y. Yamashita, S. Ueda, K. Kobayashi, N. Okazaki, I. Matolinova, V. Matolin, Electrochim. Acta, 56 (2011) 3874-3883.

[138] H. Lv, N. Cheng, T. Peng, M. Pan, S. Mu, J. Mater. Chem., 22 (2012) 1135-1141.

[139] H.F. Lv, S.C. Mu, N.C. Cheng, M. Pan, Appl. Catal., B, 100 (2010) 190-196.

[140] J. Ma, A. Habrioux, N. Guignard, N. Alonso-Vante, J Phys Chem C, 116 (2012) 21788-21794.

[141] D.-J. Guo, Z.-H. Jing, J. Power Sources, 195 (2010) 3802-3805.

[142] Z. Sun, X. Wang, Z. Liu, H. Zhang, P. Yu, L. Mao, Langmuir, 26 (2010) 12383-12389.

[143] N.I. Andersen, A. Serov, P. Atanassov, Appl. Catal., B, 163 (2015) 623-627.

[144] Z.I. Bedolla-Valdez, Y. Verde-Gómez, A.M. Valenzuela-Muñiz, Y. Gochi-Ponce, M.T. 
Oropeza-Guzmán, G. Berhault, G. Alonso-Núñez, Electrochim. Acta, 186 (2015) 76-84.

[145] C. Zhou, H. Wang, F. Peng, J. Liang, H. Yu, J. Yang, Langmuir, 25 (2009) 7711-7717.

[146] X. Lou, J. Chen, M. Wang, J. Gu, P. Wu, D. Sun, Y. Tang, J. Power Sources, 287 (2015) 203-210.

[147] S. Shanmugam, A. Gedanken, Small, 3 (2007) 1189-1193.

[148] M.C. Orilall, F. Matsumoto, Q. Zhou, H. Sai, H.D. Abruna, F.J. DiSalvo, U. Wiesner, J. Am. Chem. Soc., 131 (2009) 9389-9395.

[149] N. Cheng, M.N. Banis, J. Liu, A. Riese, X. Li, R. Li, S. Ye, S. Knights, X. Sun, Adv. Mater., 27 (2015) 277-281.

[150] A.Z. Weber, A. Kusoglu, J. Mater. Chem. A, 2 (2014) 17207-17211. 


\section{Graphitic abstract:}

PEM fuel cell is among key electrochemical energy technologies for a sustainable society; Electrocatalyst support materials are key components for PEM fuel cells. Three types of important support materials: carbon, non-carbon and hybrid carbon-oxides nanocomposites are reviewed in this article.

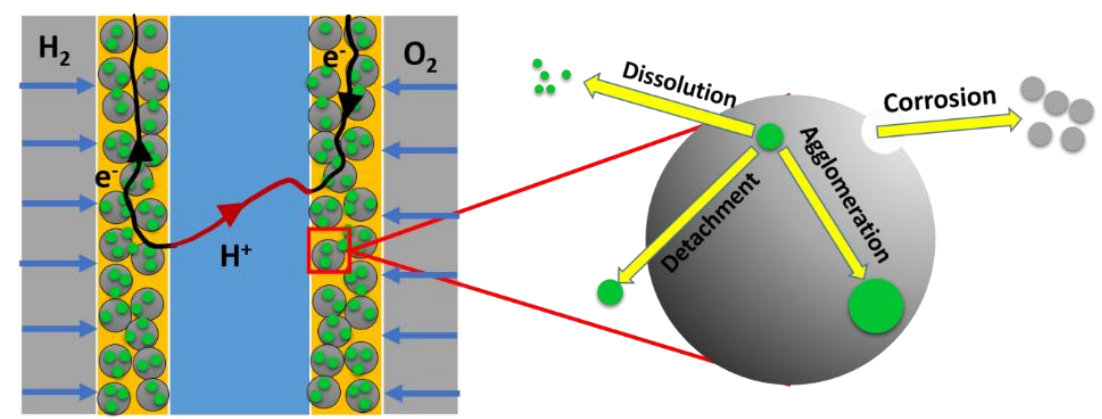




\section{Biosketch:}

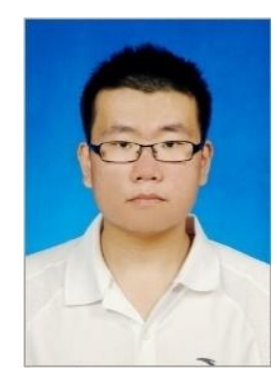

Lei Du got his bachelor's degree of engineering at the year of 2011 from Harbin Institute of Technology, China and is currently a $\mathrm{PhD}$ student at Harbin Institute of Technology supervised by Prof. Geping Yin. He is studying at Pacific Northwest National Laboratory and Washington State University as a visiting student directed by Dr. Yuyan Shao and Prof. Yong Wang. His main research interests include chemical conversion in electrocatalysis, mechanism and devices.

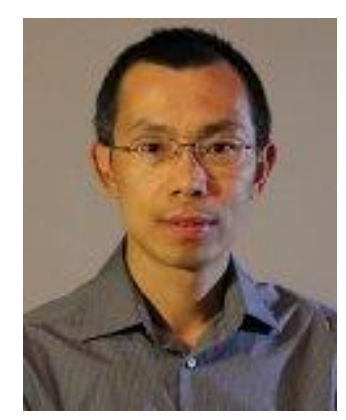

Dr. Yuyan Shao received his Ph.D. from Harbin Institute of Technology. He is a Senior Scientist at the US DOE Pacific Northwest National Laboratory. His research is focused on the fundamental study and high performance functional materials for electrochemical energy conversion and storage, including fuel cells, batteries, supercapacitors, etc. He is named in Thomson Reuters' Highly Cited Researchers-2014. He has published over 90 papers.

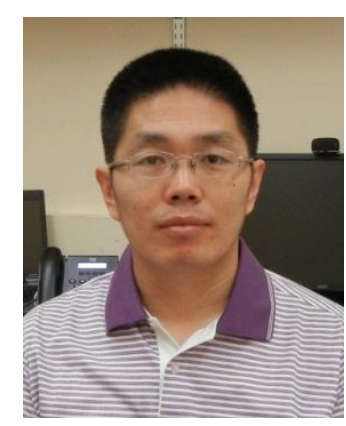


Dr. Junming Sun is an assistant research \& major professor in Prof. Yong Wang's group at Washington State University, USA. He received his PhD from Dalian Institute of Chemical Physics of Chinese Academy of Science in 2007 (Supervised by Prof. Xinhe Bao), after which he worked with Prof. Bruce C. Gates at UC Davis (2007-2008) and then with Prof. Yong Wang at Pacific Northwest National Laboratory (2008-2011) as a postdoc researcher. His current research interests include fundamental understanding and rational design of acid-base/supported metal catalysts for biomass derived small oxygenates, bimetallic catalysts for hydrodeoxygenation.

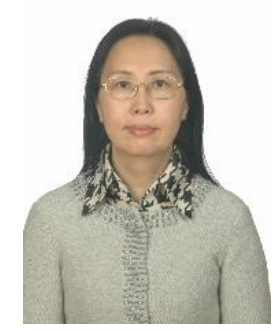

Dr. Geping Yin is a professor in School of Chemical Engineering and Technology at Harbin Institute of Technology. She got the $\mathrm{PhD}$ degree at the year of 2000 at Harbin Institute of Technology supervised by Prof. Derui Zhou. Prof. Yin went to Tokyo Institute of Technology (1985) and Yokohama National University (2008) as a visiting scholar. She focuses on the fields of advanced electrode materials, chemical power sources systems et al.

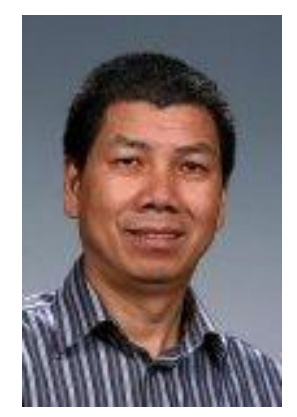

Dr. Jun Liu received his Ph.D. in materials science from University of Washington. He is a Laboratory Fellow and Energy Processes and Materials Division Director at the PNNL. His main research interest includes synthesis of functional nanomaterials for energy storage, catalysis, environmental separation and health care. He has received more than 55 U.S. patents, two R\&D 100 Awards, two BES Awards for Significant Impact on DOE Missions, 
and was named 2007 Distinguished Inventor of Battelle and Pacific Northwest national Laboratory Inventor of the Year in 2013. He is a Fellow for the Materials Research Society (MRS) and a Fellow for the American Association for Advancement of Science (AAAS). He is named in Thomson Reuters' Highly Cited Researchers 2014 and 2015.

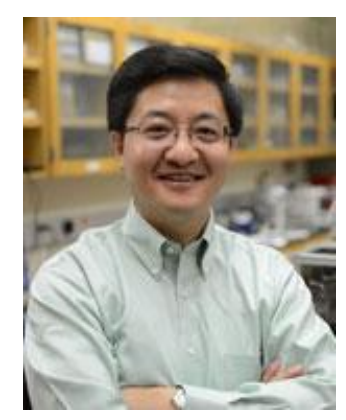

Dr. Yong Wang is a Laboratory Fellow a Pacific Northwest National Laboratory, Associate Director of the Institute for Integrated Catalysis (http://iic.pnl.gov) since 2008. In 2009, Dr. Wang assumed a joint position at Washington State University and PNNL. Dr. Wang has authored $>215$ peer reviewed publications with $\mathrm{H}$ index $=55$ and more than 13,000 citations (Google Scholar Citations). He is the inventor on 251 issued patents including 97 issued U.S. patents (>90\% of his patents are licensed to industries). He was recently elected to the fellow of National Academy of Inventors (NAI) and the member of the Washington State Academy of Science (WSAS), and is a fellow of 4 major professional societies: AIChE (American Institute of Chemical Engineers), ACS (American Society of Chemistry), RSC (Royal Society of Chemistry), and AAAS (American Association of the Advancement of Science). He has won numerous awards including Presidential Green Chemistry Award, 3 R\&D 100 Awards, 2 PNNL Inventor of the Year Awards, Battelle Distinguished Inventor Award. 